\title{
Technology Corner: Dating of Electronic Hardware for Prior Art Investigations
}

Sellam Ismail

VintageTech

Follow this and additional works at: https://commons.erau.edu/jdfsl

Part of the Computer Engineering Commons, Computer Law Commons, Electrical and Computer Engineering Commons, Forensic Science and Technology Commons, and the Information Security Commons

\section{Recommended Citation}

Ismail, Sellam (2012) "Technology Corner: Dating of Electronic Hardware for Prior Art Investigations," Journal of Digital Forensics, Security and Law. Vol. 7 : No. 1 , Article 7.

DOI: https://doi.org/10.15394/jdfsl.2012.1115

Available at: https://commons.erau.edu/jdfsl/vol7/iss1/7

This Article is brought to you for free and open access by

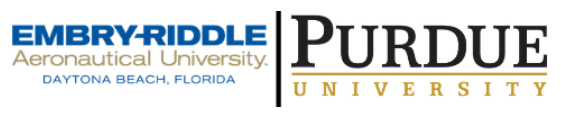
the Journals at Scholarly Commons. It has been accepted for inclusion in Journal of Digital Forensics, Security and Law by an authorized administrator of Scholarly Commons. For more information, please contact commons@erau.edu.

(c)ADFSL 


\title{
Technology Corner
}

\section{Dating of Electronic Hardware for Prior Art Investigations}

\author{
Sellam Ismail \\ VintageTech \\ sellam@ vintagetech.com \\ http://vintagetech.com
}

\section{INTRODUCTION AND BACKGROUND}

In many legal matters, specifically patent litigation, determining and authenticating the date of computer hardware or other electronic products or components is often key to establishing the item as legitimate evidence of prior art. Such evidence can be used to buttress claims of technologies available or of events transpiring by or at a particular date.

In 1945, the Electronics Industry Association published a standard, EIA 476-A, standardized in the reference Source and Date Code Marking (Electronic Industries Association, 1988). The introduction describes the reference thusly:

This Standard was formulated for the purpose of describing an easily understood coding system that has been sponsored and operated by the Electronic Industries Association (EIA) since 1945, for the identification of the manufacturing source and the date of manufacture of an electronic component or equipment. Currently 585 manufacturers are participating in the program. A user may determine who manufactured the component or equipment or when it was manufactured through reference to the EIA Source and Date Code Listing, or by direct contact with EIA.

The scope of the document is further indicated:

This Standard describes a system for identification of the manufacturer of an electronic component or equipment through the manufacturer's marking the product with a series of numbers not exceeding eight digits known as the EIA Source and Date Code. When a manufacturer so requests, the Electronic Industries Association (EIA) assigns a one to four digit Source Code to the manufacturer. EIA additionally provides a scheme for standardization of the calendar year and week in a Date Code [emphasis added].

A 1994 edition of the reference (Electronic Industries Association, 1994) describes the "EIA Source Code" as: 
...a numeric symbol, assigned and registered by EIA Headquarters, which may be stamped or marked on any or all products to identify the production source or the vendor assuming product responsibility. The EIA code, in addition, provides for adding numerals to the source code symbol to identify the year and week of production [emphasis added].

The document goes on to describe how the date code is encoded:

In addition to a source code, it may be desired to identify the date of production. This can be done by adding, following a hyphen (-), the last two digits of the production year plus the number of the week of that year.

A hypothetical example of the application of the EIA date code to the source code follows: Say a company is assigned the source code 113 . To this is added two digits for the year - such as " 94 " for the current year, or "95" for 1995 - and another tow[sic] digits for the week of the year. The combined source and date codes would be, in this case "1139410 ", which would represent the company's number " 113 " plus " 94 " for 1994, the production year, and "10" for the week of March 6-12, the production week.

If a component manufacturer is unable to use the four-digit date code, and[sic] alternate three-digit code may be used by taking only the last digit of the year. The example above would then become "113-410".

The standard document was split into two in 1998, with the Source Code markings (the manufacture's unique identification code) requirements remaining in EIA 476-A, while the Date Code marking requirements were moved to a new publication, EIA 476-B.

Industry practice has discovered that it is sometimes possible to narrow down a date code further to a specific day, as explained in an online technical note (Weber Vintage Sound Technologies, 1997):

"Some manufacturers also attached other letters to the end of the date code to indicate day of the week, work shift, serial number, lot number, etc. The EIA only specifies manufacturer and year/week code. Anything else is at the discretion of the manufacturer." 
One industry participant, however, cautions that, despite the standards, in practice the date format is inconsistent across manufacturers (AVNET Logistics, 2009):

\begin{abstract}
"The activities of Standardization Committees have positively influenced the Electronics Industry in many areas, however the production date coding of electronic components has still no unified format. Depending on the packaging, device size, product type, manufacturing country, producing factory and subsidiaries, date code formats vary significantly by supplier or even within suppliers."
\end{abstract}

In the author's experience, locating and interpreting date codes tends to be more art than science, but once identified they can be reliably established as conclusive and cognizable evidence in a courtroom.

\title{
THE METHOD APPLIED
}

The first step in locating a date code is to start on the exterior. If we are examining a discrete component then we would try to find a 4-digit numeric string as that would most likely be the date code. If we are examining a finished product then we might first want to start by looking at the product label or any other stickers on the back or bottom of the product. If we find none, we must then have a look inside, which means disassembling the unit. Once inside, we again look for any labels or stickers that might indicate a date of manufacture. If we again find none, we must now turn our sights to the individual components and examine their individual date code markings.

\section{A Supporting Survey}

An actual study undertaken in a prior art examination in support of the respondent in the case Comaper v. Antec (2010) is published herein. The dispute revolved around a patent taken out by Comaper for a computer fan product. Comaper sued Antec for patent infringement. Antec lost but the decision (by jury) was overturned on appeal, setting precedent, and a new trial was granted to Antec on validity. Antec lost the second trial and the decision (also by jury) is on appeal as of this writing.

The author was hired by Antec as one of its supporting expert witnesses in the case. Incident to the project, the author conducted a study (Figure 1) of a number of computers in the author's private archive of computers, seeking machines with a particular configuration of fan devices built prior to a critical date of December 1993. To positively date each computer to establish that each was built prior to the critical date, every component on every card or module was examined to make sure that no claim could be made otherwise. The chart in Figure 1 lists all the date codes found in each of 10 computers located and examined during the investigation and used as supporting evidence in determining the manufacture dates of the computers. 
In the instant example, a variety of chips across a multitude of manufactures were examined. Most all exhibited YYWW (year/week) format date codes, which is typical for integrated circuit chips (ICs).

\section{Summary, Conclusions and Further Work}

The dating of electronic components can be made based on reliable published industry standards in place since at least 1945. Actual field work has demonstrated conclusively that date codes are in practice a reliable method for determining accurate dates of manufacture for specific components and, by inference and with supporting evidentiary material, finished products that are comprised of date coded components. 


\begin{tabular}{|c|c|}
\hline Hardware Item & Date Code Evidence \\
\hline Sun $386 i / 250$ & $\begin{array}{l}\text { Date codes of ICs on Memory Board (8801-8831 range) } \\
\text { Date code of } 8838 \text { stamped on power supply } \\
\text { Hard Disk ICs (9109-9130 range) - most likely was a later upgrade; the } \\
\text { Memory Board and Power Supply date codes are more reliable in this } \\
\text { instance } \\
\text { This computer was most likely built in } 1988 \text { but was certainly available no } \\
\text { later than } 1991 \text {. }\end{array}$ \\
\hline $\begin{array}{l}\text { Control Data Cyber } \\
910\end{array}$ & $\begin{array}{l}\text { Ink date stamp of "JUN } 261988 \text { " on drive bay modules } \\
\text { Date code of } 8826 \text { stamped on main housing } \\
\text { Written date on sticker on main housing ("7-6-88" and "7-16") } \\
\text { Handwritten date codes on cable labels ("6-28", "6-30") } \\
\text { The "7-16" hand-written date code on the housing sticker probably indicates } \\
\text { this machine was ready for shipping on July 16, 1988. At any rate it was } \\
\text { certainly built no later than 1988. }\end{array}$ \\
\hline IBM RS/6000 58H & $\begin{array}{l}\text { "Announced: 1993/09/21; Available: 1993/10/22" } \\
\text { IBM eServer pSeries Systems Handbook 2003 Edition, p959 (999 PDF) } \\
\text { http://www.redbooks.ibm.com/redbooks/pdfs/sg245120.pdf } \\
\text { Date codes on side cover panels ("9 } 1294 " \text { " "6 } 28 \text { 94", "SEP 19 94", and } \\
\text { "SE[P] } 2094 ") \\
\text { Date code on power supply label ("9438", which is mid-October 1994) } \\
\text { Manufacturing of this computer seems to have been completed by the } \\
\text { middle of October 1994. At any rate it was certainly built no later than the } \\
\text { end of October of } 1994 . \\
\text { I also have other models in this series, including the } 530 \text { (available June } \\
\text { 1990) and } 560 \text { (available June 27, 1992). I examined both and they have a } \\
\text { very similar design to the 58H, including the general computer housing } \\
\text { configuration as well as the drive bay modules. }\end{array}$ \\
\hline $\begin{array}{l}\text { IBM AS/400 Type } \\
9404\end{array}$ & 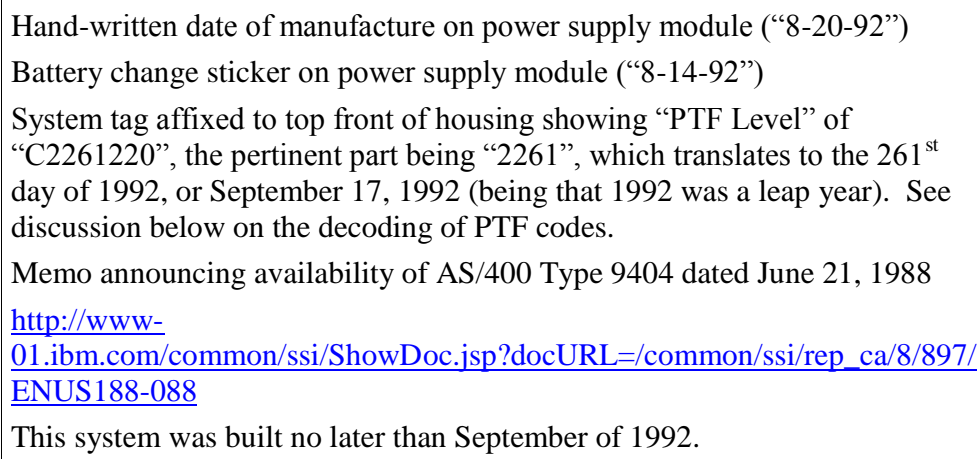 \\
\hline
\end{tabular}

Figure 1: Date Code Evidence Chart for Comaper v. Antec (Part I) 
Journal of Digital Forensics, Security and Law, Vol. 7(1)

\begin{tabular}{|c|c|}
\hline Hardware Item & Date Code Evidence \\
\hline Data General Nova 3 & $\begin{array}{l}\text { Date codes of ICs on control boards: } \\
\text { CHAN I (8434-8547 range) } \\
\text { READ PL0 (8428-8611 range, "08 1986" on PCB) } \\
\text { WRITE PL0 (8415-8605 range, “04 86" on PCB) } \\
\text { CPU CONTROL (8351-8449 range, "0485" on PCB) } \\
\text { FAULT CONTROL (8420-8541, "8502" on PCB) } \\
\text { SERVO ( } 8435-8436 \text {, "3984" on PCB) } \\
\text { Date code on voice coil of hard disk (8606) } \\
\text { Date code of "10/84” stamped on drive belt } \\
\text { This hard drive module (CDC Mini-Module Drive) was built no later than } \\
\text { 1986. }\end{array}$ \\
\hline $\begin{array}{l}\text { PCC } 2000 \text { Fan } \\
\text { Module }\end{array}$ & $\begin{array}{l}\text { Date stamp of "5-18-81" on inside of case } \\
\text { Date stamp of "3380" on fans } \\
\text { Adjacent panels in the drive bay housing were stamped in a similar manner } \\
\text { with "6/81" and " } 5 / 27 / 81 \text { " (see photos) } \\
\text { Hand-written label on Pertec hard disk installed in drive bay ("3-9-81") and } \\
\text { body stamped with "FEB } 271981 \text { " } \\
\text { The fan module was built on May 18, } 1981 \text { (per the date stamp). The rest of } \\
\text { the drive bay (Pertec model 4246) was manufactured no later than June of } \\
1981 . \\
\text { See also additional e-mail communications between me and a representative } \\
\text { at ETRI, the fan manufacturer, confirming the date codes on the fans, below. }\end{array}$ \\
\hline Symbolics 3600 & $\begin{array}{l}\text { Copyright on CPU board (1984) and IC date codes ranging from 1984-86 } \\
\text { Copyright on Memory board of } 1984 \\
\text { Copyright on DATA PATH board of 1983,84 } \\
\text { Hand-written date on IO TEST board label (“4/21/83") and IC date codes } \\
\text { ranging from 1982-83 } \\
\text { Copyright date on FRONT END board (1984) and IC date codes ranging } \\
\text { from 1985-86 } \\
\text { Copyright date on INSTRUCTION FGETCH UNIT (1985), date code on } \\
\text { PCB (“08-86"), and IC date codes ranging from 1985-86 } \\
\text { Copyright date on EXTENDED SEQUENCER board (1985) and IC date } \\
\text { codes ranging from 1985-86 } \\
\text { Date code on Fujitsu hard disk power supply label ("1982-9") } \\
\text { "Defect List" print-out attached to Fujitsu hard disk cover (stamped } \\
\text { "82.09.03") } \\
\text { This machine was likely built in } 1983 \text { but was available certainly no later } \\
\text { than } 1986 .\end{array}$ \\
\hline
\end{tabular}

Figure 1: Date Code Evidence Chart for Comaper v. Antec (Part II) 
Journal of Digital Forensics, Security and Law, Vol. 7(1)

\begin{tabular}{|l|l|}
\hline Hardware Item & Date Code Evidence \\
\hline $\begin{array}{l}\text { Nuclear Data 9900 } \\
5.25 \text { " Drive Bay } \\
\text { Module }\end{array}$ & $\begin{array}{l}\text { Date stamp of "4586" on backplane board } \\
\text { Date codes on backplane ICs (8507-8628 range } \\
\text { Date codes on drive module PCB (8551-8628 range) } \\
\text { This machine was built no later than 1986. }\end{array}$ \\
\hline $\begin{array}{l}\text { Nuclear Data 9900 } \\
\text { Mujitsu Drive }\end{array}$ & $\begin{array}{l}\text { Date codes on product labels on power supplies ("1986-8" and "1986-9") } \\
\text { Date codes on left hard disk ICs (8605-8629 range) } \\
\text { Date codes on right hard disk ICs (8434-8531 range) } \\
\text { This subsystem was built no later than 1986. }\end{array}$ \\
\hline Stardent Titan & $\begin{array}{l}\text { Shipping date of "9/19/91" is hand-written on a label on the housing. } \\
\text { Copyright date on CPU board of 1989 and IC date codes ranging from } \\
1989-1990 \\
\text { Date stamps of "05/15/90" and "06/15/89" on labels affixed to cables } \\
\text { inside drive module } \\
\text { The shipping date on the housing label clearly shows this machine was } \\
\text { built in 1991. }\end{array}$ \\
\hline IBM PS/2 Model 55 & $\begin{array}{l}\text { Copyright date on label on back of housing (1990) } \\
\text { Ink date stamp on vent cover ("JAN 05 1990") } \\
\text { This computer was built no later than 1990. }\end{array}$ \\
\hline
\end{tabular}

Figure 1: Date Code Evidence Chart for Comaper v. Antec (Part III)

\section{REFERENCES}

AVNET Logistics. (2009). Date Code Identification. Retrieved March 21, 2012 from http://www.avnet-logistics.eu/services/product-date-codes.html

Comaper Corp. v. Antec Inc., Nos. 2009-1248, 2009-1249 (United States Court of Appeals, Federal Circuit 2010)

Electronic Industries Association. (1988). Source and Date Code Marking. Washington, D.C.: EIA.

Electronic Industries Association. (1994). Source and Date Code Marking. Washington, D.C.: EIA.

Weber Vintage Sound Technologies. (1997). Speaker Codes And What They Mean. Retrieved March 21, 2012 from http://www.webervst.com/codes.html 
Journal of Digital Forensics, Security and Law, Vol. 7(1) 